\title{
OSTEOMALACIA CAUSED BY VITAMIN D DEFICIENCY WITH PSEUDOFRACTURES (LOOSER ZONES) IN THE BILATERAL FEMUR AS CAUSE OF PAIN IN ELDERLY PATIENT
}

Andressa Higa Shinzato1,*, Felipe de Lacerda Veiga ${ }^{1}$, Guilherme Pereira Carlesso ${ }^{1}$, Heloísa Rodrigues Silva Catalá ${ }^{1}$, Isadora Medina ${ }^{1}$, Marcela Miguens Castelar Pinheiro ${ }^{1}$, Stella Falcadi Vendramine ${ }^{1}$, Pedro Matos ${ }^{1}$, Diogo Souza Domiciano ${ }^{2}$, Flávio Duarte Silva ${ }^{3}$, Marcos Hajime Tanaka², Edgard Torres dos Reis Neto ${ }^{1}$

1. Universidade Federal de São Paulo, São Paulo (SP), Brazil. 2. Hospital Alemão Oswaldo Cruz, São Paulo (SP), Brazil. 3. Fleury Medicina e Saúde, São Paulo (SP), Brazil.

*Corresponding author: dessa_higa@hotmail.com

\section{BACKGROUND}

Osteomalacia is a disease characterized by defective bone mineralization during its remodeling. Clinical symptoms associated with osteomalacia include bone pain, weakness, fractures, and gait changes. Severe and prolonged vitamin D deficiency and hypophosphatemia are the main causes of osteomalacia.

\section{CASE REPORT}

A 79-year-old white woman, without previous comorbidities, was admitted due to pain in the gluteal and posterior region of the right thigh, with gait disturbance, associated with loss of $6 \mathrm{~kg}$. On physical examination, she presented loss of weight (weight $46 \mathrm{~kg}$, BMI 19.5), with palpable tumor without phlogistic signs, soft and painless, in the gluteus and posterior region of the right thigh. Laboratory examination revealed Hb $9.3 \mathrm{~g} / \mathrm{dL}$ (hypochromic/microcytic), C-reactive-protein $0.26 \mathrm{mg} / \mathrm{dL}$, high erythrocyte sedimentation rate $102 \mathrm{~mm}(1 \mathrm{~h}$ ), creatinine $0.6 \mathrm{mg} / \mathrm{dL}$, low serum calcium $5.8 \mathrm{mg} / \mathrm{dL}$ (normal range $>8.5 \mathrm{mg} / \mathrm{dL}$ ), serumalbumin $4.0 \mathrm{~g} / \mathrm{dL}$, serum phosphorus $3.6 \mathrm{mg} / \mathrm{dL}$, serum alkaline phosphatase $368 \mathrm{U} / \mathrm{L}$ (normal range $<120 \mathrm{U} / \mathrm{L}$ ) with other liver tests normal. She had low levels of 25-hydroxyvitamin D $(<4 \mathrm{ng} / \mathrm{mL}$ ), high intact parathyroid hormone $367 \mathrm{pg} / \mathrm{mL}$, normal protein electrophoresis and immunofixation test without monoclonal peak. Magnetic resonance imaging (MRI) (Figs. 1 and 2) of right thigh showed a voluminous mass $(18.7 \times 9.2 \times 6.4 \mathrm{~cm})$ with adipose content between the gluteus maximal and gluteus medius, in contact with the posterior face of the proximal femur, displacing the sciatic nerve. The MRI also showed areas of sclerotic borders on the proximal femur, corresponding to incomplete fractures due to insufficiency/pseudofractures (Looser's zones). Biopsy of the lesion revealed the presence of low-grade liposarcoma and, in view of the diagnosis of osteomalacia, treatment was performed with cholecalciferol 50,000 IU/week for 8 weeks followed by 7,000 IU/week and calcium $1 \mathrm{~g} /$ day with significant improvement of pain and normalization of levels of 25-hydroxyvitamin D ( $52 \mathrm{ng} / \mathrm{mL}$ ), serum calcium ( $9.4 \mathrm{mg} / \mathrm{dL}$ ) and parathyroid hormone (48 pg/mL).

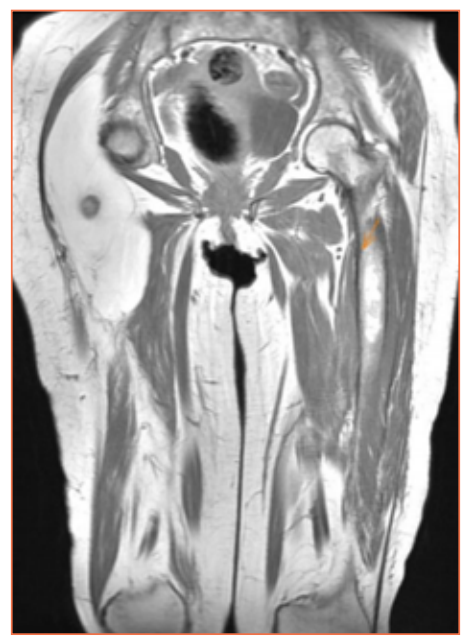

Figure 1. The MRI showed Looser's zones (on the arrows) and a mass on the right thigh. 


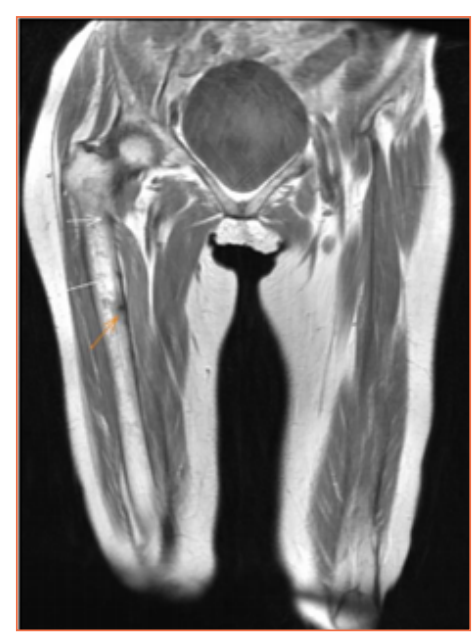

Figure 2. The MRI showed Looser's zones (on the arrows).

\section{CONCLUSION}

This report shows a case of osteomalacia with significant pain due to pseudofractures (Looser's zones) secondary to severe vitamin $\mathrm{D}$ deficiency. Since vitamin $\mathrm{D}$ plays an important role in bone mineralization, special attention should be given to elderly population with frailty. 